\title{
TERÉNNÍ GAMASPEKTROMETRICKÁ CHARAKTERISTIKA PSAMITŮ GODULSKÉHO SOUVRSTVÍ: VYUŽITÍ PRO INTERPRETACI JEJICH VZNIKU
}

Field gamma-ray spectrometric characteristics of arenites of the Godula Formation and its genetic interpretation

\author{
Daniel Šimíček ${ }^{1,2}$, Ondřej Bábek ${ }^{1,2}$ \\ 1 Ústav geologických věd PřF MU, Kotlářská 2, 61137 Brno \\ ${ }^{2}$ Katedra geologie PřF UP, Tř. Svobody 26, 77146 Olomouc; e-mail: daniel.simicek@upol.cz
}

Key words: Godula Formation, gamma-ray spectrometry, sandstone petrography, provenance, stratigraphy

\begin{abstract}
Our study was focused on low to medium radioactive sandstones of the Godula Formation of the external flysch zone of the Western Carpathians. It is widely known that concentrations of radioactive elements ( $K, U$ and $T h)$ in siliciclastic sediments are primary controlled by facies and mineral and chemical composition, which is largely influenced by their provenance. In the Godula Formation, $K$ was found to be predominantly incorporated in some framework and accessory detritic minerals (K-feldspars, albite, mica, glauconite, illite). Main sources of $U$ and Th were identified in heavy minerals, such as monazite and zircon. Variations of $K, U$ and Th concentrations correspond to changes in modal composition of sandstones and indicate uplift and subsequent erosion of structurally deeper crustal parts of source area (Silesian Ridge). Significant increase of $K, U$ and Th concentrations was observed near the boundary between the Middle and Upper Godula beds. Gamma-ray spectrometry could be used as good supplementary technique for discrimination of sandstones of these lithostratigraphical parts of the Godula Formation.
\end{abstract}

Úvod

Gamaspektrometrie (GRS) na výchozech sedimentů je hojně využívanou petrofyzikální metodou (Van Wagoner et al. 1990, Slatt et al. 1992, Šimíček et al. 2012). Siliciklastické sedimenty jsou typické svým pestrým chemickým a minerálním složením, které primárně odráží vlivy horninového složení zdrojové oblasti (provenience) a vlastnosti transportu a depozičního prostředí (facie). Pro naše studium jsme si vybrali svrchnokřídové synorogenní psamitické sedimenty godulského souvrství vněkarpatského flyšového pásma. Jejich pestré modální složení indikuje provenienční změny způsobené výzdvihem a následnou hloubkovou erozi zdrojové oblasti (Grzebyk - Lesczyñski 2006). Vhodně zvolenou metodikou dokáže gamaspektrometrie poměrně citlivě reagovat na tyto změny. Naším cílem je zjistit použitelnost metody pro studium provenience klastického materiálu pískovců.

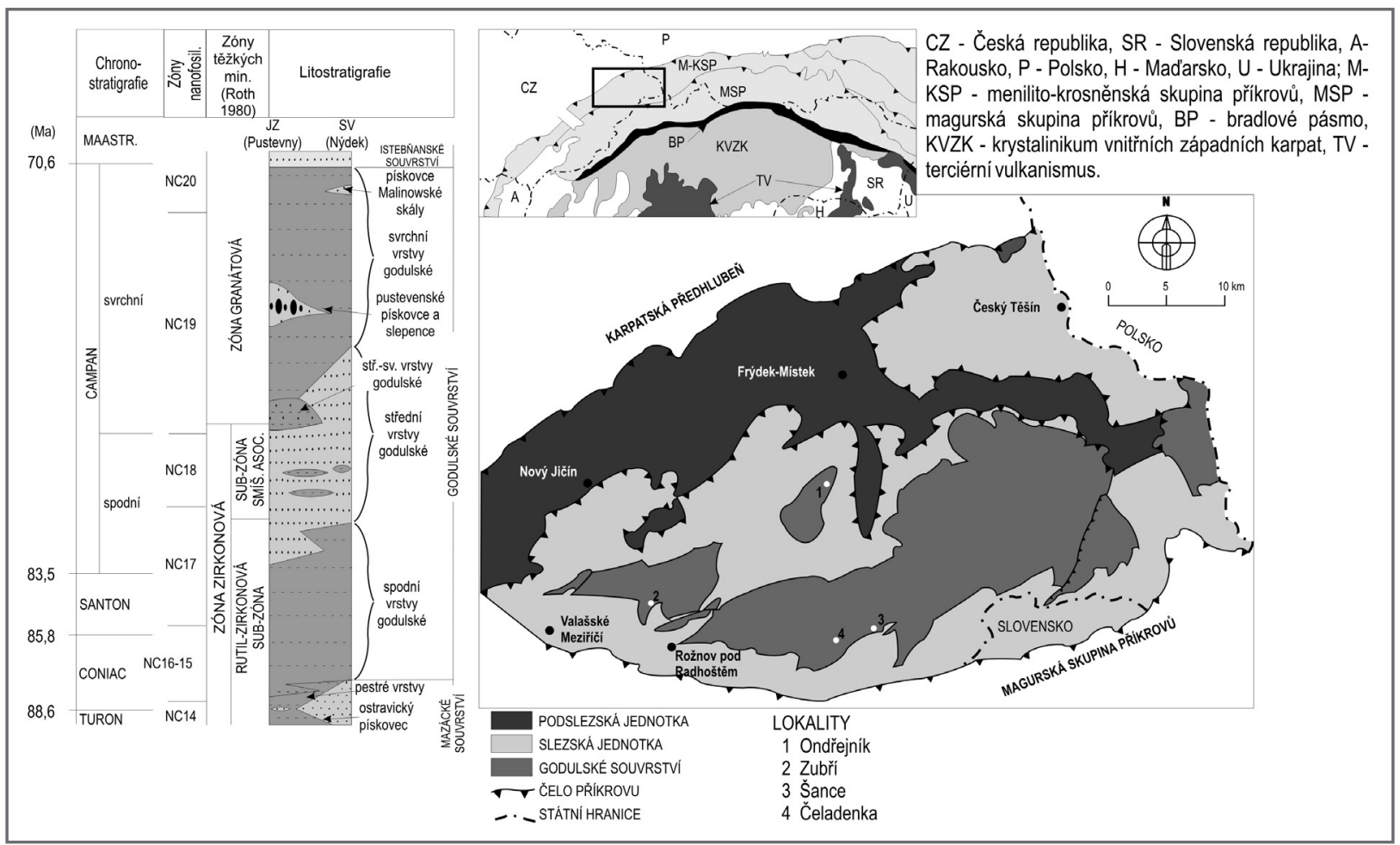

Obr. 1: Schematická geologická mapa slezské jednotky upravená podle Menčíka et al. (1983).

Fig. 1: Geologic sketch-map of the Silesian Unit modified after Menčík et al. (1983). 


\section{Geologická charakteristika}

Godulské souvrství tvoří kostru godulského vývoje slezské jednotky menilito-krosněnské skupiny flyšových příkrovů Vnějších Západních Karpat. Maximální mocnost synorogenních, hlubokomořských sedimentů přesahuje $3000 \mathrm{~m}$ (Roth 1980). Litostratigraficky můžeme godulské souvrství členit na spodní (?coniac/santon až nejspodnější campan), střední (spodní

Tab. 1: Základní popis pozorovaných pískovcových facií.

Tab. 1: Basic description of observed sandstone facies.

\begin{tabular}{|c|c|c|c|}
\hline faciální typ & F1 & $\mathrm{F} 2$ & F3 \\
\hline litologie & $\begin{array}{l}\text { středně až hrubě zrnité } \\
\text { pískovce }\end{array}$ & $\begin{array}{l}\text { stř̌edně až jemně zrnité } \\
\text { pískovce }\end{array}$ & $\begin{array}{l}\text { jemnozrnné pískovce až } \\
\text { prachovce }\end{array}$ \\
\hline $\begin{array}{l}\text { sedimentární } \\
\text { struktury }\end{array}$ & $\begin{array}{l}\text { masivní, občas slabá nor- } \\
\text { mální gradace, na bázi může } \\
\text { být tenká poloha slepenců, } \\
\text { u stropu zřídka nevýrazné } \\
\text { planární zvrstvení, hojné } \\
\text { mísovité struktury, při bázi } \\
\text { se může vyskytovat trakční } \\
\text { koberec }\end{array}$ & $\begin{array}{l}\text { normální gradace, na bázi } \\
\text { až hrubozrnný pískovec, } \\
\text { planární laminace, u stropu } \\
\text { čeřinová laminace, občas } \\
\text { konvoluce, amalgamace, } \\
\text { oddělení boumovy sekvence } \\
\text { Tb,c }\end{array}$ & $\begin{array}{l}\text { planární laminace, občas } \\
\text { normální gradace, oddělení } \\
\text { boumovy sekvence } \mathrm{T}(\mathrm{b}), \mathrm{c}, \mathrm{d}\end{array}$ \\
\hline mocnost vrstvy & $0,3-3 \mathrm{~m}$ & $10-30 \mathrm{~cm}$ & $\sim \mathrm{cm}-10 \mathrm{~cm}$ \\
\hline $\begin{array}{l}\text { vrstevní kontakt, } \\
\text { vrstevní geometrie }\end{array}$ & $\begin{array}{l}\text { časté bazální výmoly, plochý } \\
\text { svrchní kontakt, vrstevní } \\
\text { geometrie neznámá }\end{array}$ & $\begin{array}{l}\text { plochý spodní i svrchní } \\
\text { kontakt }\end{array}$ & $\begin{array}{l}\text { zvlněná báze s občasnou } \\
\text { prítomností mechanoglyfů } \\
\text { nebo bioglyfů, plochý svrchní } \\
\text { kontakt, občas laterálně } \\
\text { vykliňují }\end{array}$ \\
\hline $\begin{array}{l}\text { intraklasty, } \\
\text { přerostlé } \\
\text { extraklasty }\end{array}$ & $\begin{array}{l}\text { občasné jílovcové intraklasty } \\
\text { nebo plovoucí klasty vápenců } \\
\text { blízko vrstevní báze }\end{array}$ & & \\
\hline depoziční proces & $\begin{array}{l}\text { vysoce hustotní turbiditní } \\
\text { proudy }\end{array}$ & $\begin{array}{l}\text { kvasi-steady turbiditní } \\
\text { proudy }\end{array}$ & $\begin{array}{l}\text { nízko hustotní turbiditní } \\
\text { proudy }\end{array}$ \\
\hline
\end{tabular}

až svrchní campan) a svrchní (nejsvrchnější campan) vrstvy godulské (Skupien - Mohamed 2008). Biostratigrafie je založena na výskytu aglutinovaných foraminifer a cyst dinoflagelátů (Skupien - Mohamed 2008). Další stratigrafické členění poskytují asociace těžkých minerálů. Roth (1980) rozdělil sedimenty godulského souvrství do dvou zón těžkých minerálů.

Stratigraficky starší zóna zirkonová je dále členěna na podzóny rutil-zirkonovou a smíšených asociací. Zahrnuje spodní a většinu středních vrstev godulských a vyznačuje se převahou ultrastabilních těžkých minerálů (zirkon, turmalín, rutil). Mladší zóna granátová odpovídá nejsvrchnější části středních a svrchním vrstvám godulským (viz obr. 1) a dominují v ní minerály skupiny granátu, hojný je rovněž rutil a zirkon. Vývoj spodních a svrchních vrstev godulských má charakter převážně drobně až středně rytmického flyše, který je typický pro sedimentaci mezi koryty ve střední části submarinních vějírù. Případně může jít o distální turbiditní sedimenty uložené ve vnější části submarinního vějíře, s občasným přínosem hruběji klastického přelivového materiálu (Menčík et al. 1983). Mezi spodními a svrchními vrstvami godulskými je zachována hrubě rytmická sedimentace středních vrstev godulských, které představují pravděpodobně výplň laterálně migrujících koryt submarinních vějírư. Paleoproudové analýzy a modální složení sedimentů ukazuje, že hlavním zdrojem klastického materiálu byl nejspíše vnitropánevní hřbet - slezská kordiléra, oddělující depoziční prostor slezské jednotky od pánve magurské (Eliáš 1970).

\section{Materiál a metodika}

K získání terénních gamaspektrometrických dat byl použit přenosný gamaspektrometr RS-230 Super Spec se scintilačním krystalem BGO $2 \times 2$ “. Koncentrace $\mathrm{K}$ jsou stanovovány prímo. Obsahy eU a eTh přístroj automaticky přepočítá z koncentrací izotopů ${ }^{214} \mathrm{Bi}$, respektive ${ }^{208} \mathrm{Tl}$. V godulském souvrství byly vytipovány čtyři profily, na kterých bylo provedeno celkem 172 měření. Jednotlivé lokality reprezentují různé stratigrafické úrovně od spodních po svrchní vrstvy godulské. Každé měření probíhalo po dobu 240 s (cf. Svendsen-Hartley 2001), vždy v přímém kontaktu $\mathrm{s}$ měřenou horninou, kolmo $\mathrm{k}$ jejímu povrchu a alespoň $15 \mathrm{~cm}$ od ukončení vrstvy. Ke každému měřenému bodu byl přiřazen základní sedimentologický popis horniny podle běžně užívané terénní metodiky Tuckera (2003). Na základě tohoto popisu byly vyčleněny tři faciální třídy, které pokrývají zrnitostní rozsah od pískovců $s$ rozptýlenými štěrkovými klasty až po prachovité pískovce (tab. 1). Hodnoty standardního gama záření (SGR) byly vypočítány podle Schlumbergerova (NGTA) vzorce (1):

SGR $[$ API $]=\mathrm{U}[\mathrm{ppm}] .8,09+\mathrm{Th}[\mathrm{ppm}] .3,93+\mathrm{K}[\%] \cdot 16,32$ (Rider 1996).

V každém výbrusovém preparátu bylo bodovou sčítací technikou, s využitím standardní Gazzi-Dickinsonovy metodiky (Dickinson 1970), identifikováno 300 zrn. Detritická zrna písčité frakce $(0,064-2 \mathrm{~mm})$ byla členěna na kompoziční skupiny monokrystalického $(\mathrm{Qm})$ a polykrystalického křemene (Qp), draselných živců (Fk), plagioklasů (Fp) a litických klastů (L). Litické klasty byly dále děleny na úlomky sedimentárních a metasedimentárních (Ls), vulkanických a metavulkanických (Lv) a plutonických a metaplutonických (Lm) hornin (viz tab. 4). Neidentifikovatelné litické klasty jsou značeny Li. Základní hmota ani tmel nebyly počítány. Pro provenienční závěry byla data modálního složení pískovců exportována v ternárních diagramech Dickinsona et al. (1983). Identifikace možných zdrojů K, Th a U v hlavních, vedlejších a akcesorických detritických minerálech, tmelu a základní hmotě pískovců byla provedena na elektronové mikrosondě CAMECA SX 100 na PřF MU v Brně. Urychlovací napětí bylo $15 \mathrm{kV}$, proud 10-40 nA a šírka svazku 1-4 $\mu \mathrm{m}, \mathrm{v}$ závislosti na zkoumaném minerálu. Těžké minerály, které mohou být důležitým zdrojem U a Th v pískovcích a také indikátorem provenience klastického materiálu, byly separovány v těžké 
kapalině $1,1,2$, 2-tetrabromethan $\left(\mathrm{C}_{2} \mathrm{H}_{2} \mathrm{Br}_{4}\right)$ o hustotě $2,96 \mathrm{~g} / \mathrm{cm}^{3}$ v laboratoři ČGS v Praze na Barrandově. K jejich následné identifikaci byl použit binokulární mikroskop NIKON C-PS. Procentuální zastoupení jednotlivých minerálních skupin bylo zjištěno semikvantitativně.

\section{Zdroje gama záření $\mathrm{v}$ pískovcích}

Podíl K, U a Th na celkové radioaktivitě pískovců godulského souvrství je relativně rovnoměrný (lineární regresní koeficient, $\mathrm{R}^{2}=0,86$ pro $\mathrm{SGR} / \mathrm{K}, \mathrm{R}^{2}=0,81$ pro $\mathrm{SGR} / \mathrm{U}$ a $\mathrm{R}^{2}=0,94$ pro SGR/Th). Modální a chemické složení detritických zrn pískovců a asociace těžkých minerálů ukázaly, že gama záření je $\mathrm{v}$ těchto sedimentech spojeno především s obsahy detritických horninotvorných, vedlejších a akcesorických minerálů. $K$ je ve studovaných pískovcích obsažen ve všech zrnitostních frakcích. V písčité frakci je vázán na některé horninotvorné minerály, jako jsou draselné živce, muskovit, biotit (včetně částečně chloritizovaných zrn) a vzhledem ke své hojnosti také albit (průměrně 0,19 hmot. \% $\mathrm{K}_{2} \mathrm{O}$ ). V některých vzorcích je hojný také autigenní glaukonit. V prachové a jílové frakci pískovců je výskyt draslíku spojen s některými složkami základní hmoty (živce, sericit, illit, glaukonit, apatit). Hlavními zdroji uranu a thoria ve studovaných pískovcích jsou pravděpodobně těžké minerály, především monazit (prům. 0,35 hmot. \% $\mathrm{UO}_{2}$ a 4,98 hmot. \% $\mathrm{ThO}_{2}$ ) a zirkon (viz tab. 2). Nízké koncentrace $\mathrm{UO}_{2}$ a $\mathrm{ThO}_{2}$ byly zjištěny také v apatitu. Xenotim, který má obvykle vysoké obsahy U i Th, byl běžně pozorován, avšak jeho výskyt je vázán výhradně na velmi jemnou prachovou frakci a přesný chemismus nebylo možné elektronovou mikrosondou zjistit. Rovněž nelze vyloučit možnou vazbu části U na organickou hmotu. Avšak vzhledem k velice nízkým obsahům TOC v pískovcích godulského souvrství (cf. Matýsek - Skupien 2005 a Skupien - Mohamed 2008) pravděpodobně nemá organická hmota na celkové koncentrace U ve studovaných sedimentech zásadní vliv.

\section{Faciální vlivy na koncentrace $K$, U a Th ve studovaných pískovcích}

Všechny studované pískovce godulského souvrství lze označit za nízce až středně radioaktivní (prům. dávkový př́kon $62,2 \mathrm{nGy} \cdot \mathrm{h}^{-1}$; průměrné koncentrace $\mathrm{K} 2,8 \%$,
Tab. 3: Přepočtené hodnoty terénní gamaspektrometrie podle jednotlivých litostratigrafických členů godulského souvrství. SpVG - spodní vrstvy godulské, StřVG - střední vrstvy godulské, Stř̌-SvVG - střední až svrchní vrstvy godulské, SvVG - svrchní vrstvy godulské.

Tab. 3: Recalculated field GRS values according to individual lithostratigraphic members of the Godula Formation. SpVG Lower Godula beds, StřVG - Middle Godula beds, Stř-SvVG - indiscrimated Middle to Upper Godula beds, SvVG - Upper Godula beds.

\begin{tabular}{|c|c|c|c|c|c|}
\hline & \multicolumn{4}{|c|}{ godulské souvrství } \\
\hline & & SpVG & StřVG & Stř̀-SvVG & SvVG \\
\hline \multirow{4}{*}{$\begin{array}{l}\text { 离 } \\
\text { 点 } \\
\text { }\end{array}$} & medián & 122,8 & 113,7 & 122,3 & 115,7 \\
\hline & $\min$. & 95,8 & 83 & 85,15 & 62,5 \\
\hline & $\max$. & 163,6 & 138,3 & 174,3 & 169,9 \\
\hline & st. odch. & 20,44 & 15,04 & 21,64 & 25,4 \\
\hline \multirow{4}{*}{$\frac{\widehat{\partial}}{\sqrt{2}}$} & medián & 3,3 & 2,75 & 3,1 & 2,3 \\
\hline & $\min$. & 2,5 & 1,9 & 2,1 & 1,2 \\
\hline & $\max$. & 4,2 & 3,4 & 4,4 & 3,5 \\
\hline & st. odch. & 0,53 & 0,43 & 0,6 & 0,59 \\
\hline \multirow{4}{*}{ 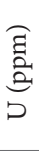 } & medián & 2,6 & 2,8 & 3,3 & 3,7 \\
\hline & $\min$. & 1,8 & 2 & 2 & 2 \\
\hline & $\max$ & 3,6 & 3,9 & 4,9 & 5,3 \\
\hline & st. odch. & 0,59 & 0,5 & 0,7 & 0,81 \\
\hline \multirow{4}{*}{$\begin{array}{l}\text { E્} \\
\text { Е } \\
\text { Е }\end{array}$} & medián & 12,1 & 11,55 & 11,8 & 13 \\
\hline & $\min$. & 9,4 & 8,5 & 8,2 & 6,6 \\
\hline & $\max$. & 17,6 & 14,7 & 16,3 & 18 \\
\hline & st. odch. & 2,27 & 1,52 & 2,3 & 2,63 \\
\hline \multirow{4}{*}{$\underset{\mathrm{E}}{\stackrel{\Delta}{\mathrm{F}}}$} & medián & 3,76 & 4,34 & 3,8 & 5,61 \\
\hline & $\min$. & 3,11 & 3,53 & 3 & 4,94 \\
\hline & $\max$. & 4,29 & 5,47 & 5 & 7,63 \\
\hline & st. odch. & 0,33 & 0,48 & 0,5 & 0,65 \\
\hline
\end{tabular}

U 2,9 ppm a Th 11,7 ppm; tab. 3). Interpretace spekter gama záření, jakožto nepř́mého ukazatele zrnitosti sedimentů (cf. Doveton 1994, Rider 1996) se v př́padě godulského souvrství nepotvrdila. V pískovcích byla zjištěna jen velmi špatná korelace mezi koncentracemi $\mathrm{K}$ (pozitivní, $\mathrm{R}^{2}=0,11$ ), Th (negativní, $\mathrm{R}^{2}=0,12$ ) a střední velikostí zrna pískovců. U pak nekoreluje vůbec. Slabý vliv zrnitosti na koncentrace $\mathrm{K}$ je pravděpodobně způsoben nízkou minerální a strukturní zralostí studovaných pískovců. V rozdílných zrnitostních frakcích se tak vyskytují minerály, které jsou schopny nést draslík, především živce a slídy. Průměrné koncentrace $U$ a Th systematicky narůstají od facie F1 k facii F3, což ukazuje na spojení těchto prvků se složkami jemnozrnných frakcí pískovců, které jsou přirozeně nejvíce obsaženy ve facii F3. Avšak nízký kompoziční kontrast mezi faciemi F1, F2 a F3 ze stejné stratigrafické úrovně způsobuje, že rozdíly průměrných koncentrací nepřevyšují 1 ppm u U a 2 ppm u Th (obr. 2). Relativně větší rozdíly lze pozorovat $v$ rámci jedné faciální třídy, ale na různých stratigrafických úrovních. U a Th vykazují systematický nárůst koncentrací 


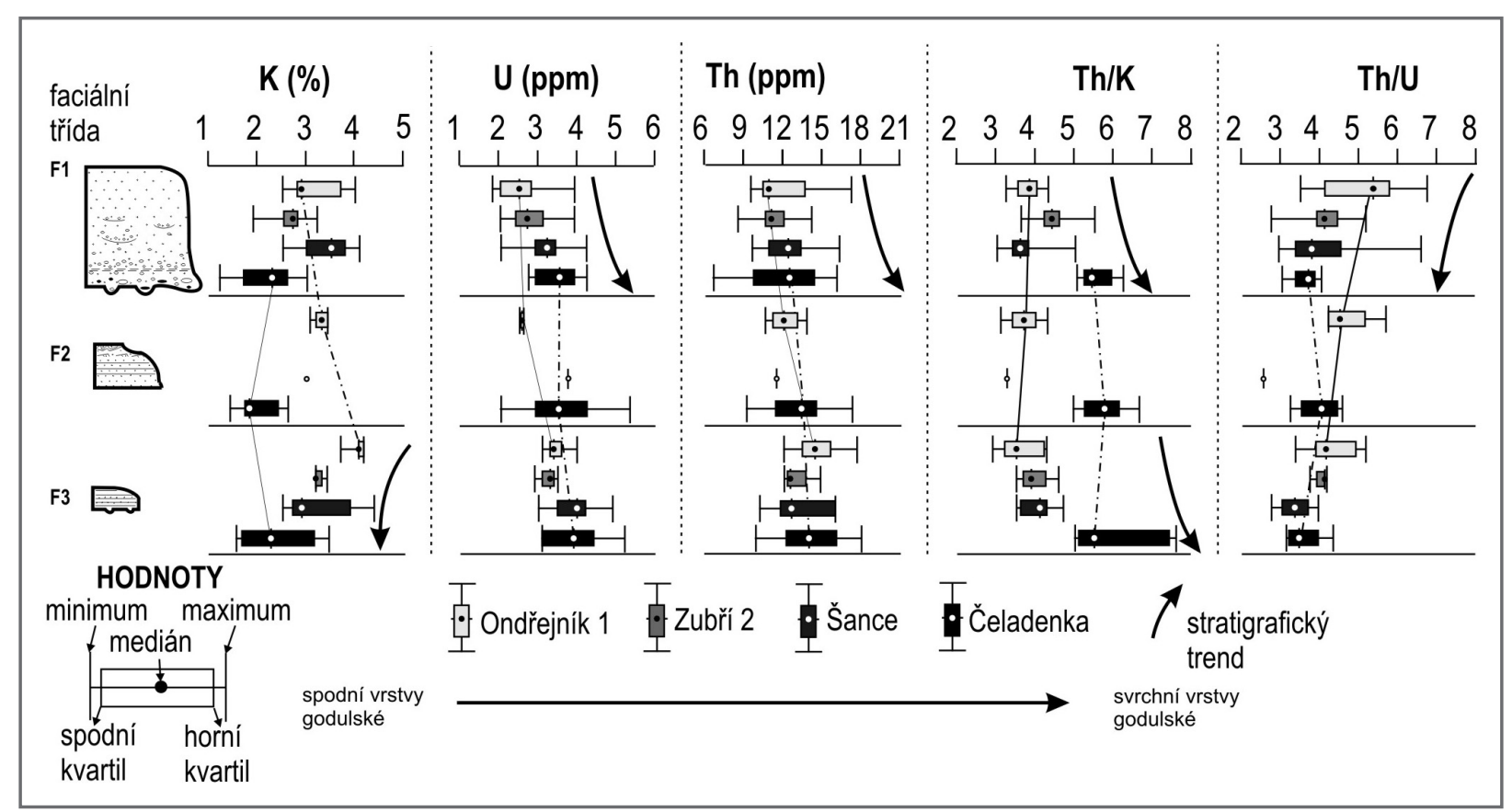

Obr. 2: Faciální distribuce koncentrací K, U a Th v pozorovaných pískovcových faciálních třídách.

Fig. 2: Facies distribution of $\mathrm{K}, \mathrm{U}$ and $\mathrm{Th}$ concentrations in observed sandstone facies classes.

do stratigraficky mladších členů godulského souvrství. Hodnoty K se naopak obecně snižují. Nejlépe lze tento trend pozorovat ve facii F2 (obr. 2), která je materiálově relativně homogenní a hodnoty nejsou ovlivňovány gama zářením z okolních vrstev. Stratigrafické změny modálního složení pískovců godulského souvrství mají na koncentrace radioaktivních prvků pravděpodobně větší vliv než hydrodynamické vytřídění v průběhu transportu a depozice.

\section{Modální složení pískovců godulského souvrství}

Modální složení studovaných pískovců je relativně monotónní a odpovídá křemen-živcovým psamitům s podružným zastoupením litických klastů (prům. Q 72\%: F $23 \%$ : L 5 \%). Ve většině prrípadů lze tyto sedimenty klasifikovat jako subarkózy. Méně časté jsou křemenné nebo drobové pískovce. Optická mikroskopie, elektronová mikrosonda a analýzy těžkých minerálů ukázaly, že převážná většina detritických zrn má svůj původ v plutonických a vysoce metamorfovaných horninách. Jejich prítomnost dokládají litické úlomky (granity, pegmatity, granulity, ruly), slabě undulozní Qm zrna, Qp zrna tvořená více než třemi subzrny, nezonální K-živce a turmalín, rutil, zirkon, monazit a granát (pyrop-almandin) v asociacích těžkých minerálů (Basu 1985, Helmond 1985, Morton 2003, Das 2008). Lokálně jsou hojné také sedimentární a metasedimentární litické klasty (tab. 4), jejichž přítomnost byla doložena úlomky vápenců, silicitů, prachovců, chloritických břidlic, slídnatých svorů a také výskytem dobře zaoblených zrn některých detritických minerálů (cf. Deer et al. 1992). Vulkanické (max. 0,6\%) a ultrabazické horniny jsou zastoupeny vzácnými klasty andezitů a ryolitů a také Cr-spinely, jejichž chemismus odpovídá peridotitům ostrovních oblouků (cf. Grzebyk - Lesczyñski 2006).

\section{Stratigrafické změny modálního složení pískovců a jejich odraz $\mathrm{v}$ koncentracích $\mathrm{K}$, U a Th}

$\mathrm{V}$ provenienčních diagramech Dickinsona et al. (1983) můžeme pozorovat změnu geotektonické provenience klastického materiálů od kratonních zdrojů a hornin přechodné kontinentální kůry ve spodních vrstvách godulských ke křemenem bohatým horninám recyklovaného orogénu ve svrchních vrstvách godulských (viz obr. 3). Obsah Qt do nadloží mírně stoupá, maxima dosahuje ve svrchních vrstvách godulských. Od spodních do svrchních vrstev godulských obecně klesají obsahy Fk a hodnoty poměru Qm/Qp (tab. 4). Rovněž se mění složení litických úlomků. Ve spodních vrstvách godulských dominují klasty granitoidů a běžně se setkáváme také $s$ vápenci, silicity a chloritickými břidlicemi (cf. Grzebyk Lesczyñski 2006). Na bázi středních vrstev godulských se ještě hojně vyskytují granátické svory, zatímco ve svrchní části středních vrstev už převládají úlomky rul, doplněné o granitoidní horniny. Ve svrchních vrstvách godulských se nejčastěji vyskytují úlomky granulitů (cf. Eliáš 2000, Pícha et al. 2006). Také asociace těžkých minerálů indikují posun provenience od granitoidních a nízko metamorfovaných hornin $\mathrm{k}$ vysoce metamorfovaným horninám bohatým granátem (cf. Unrug 1968, Speer 1980, Deer et al. 1992). Ve spodních vrstvách godulských dominují ultrastabilní těžké minerály, především turmalín a rutil, zatímco obsahy granátů se pohybují do $5 \% \mathrm{z}$ celkového podílu. Ve svrchních vrstvách godulských se situace mění a granáty pyrop-almandinového složení mohou tvořit až $55 \%$ všech zrn (viz obr. 3 ).

Celková radioaktivita pískovců evidentně reaguje na výše popsané změny v modálním složení pískovců. Vysoké obsahy živců (především K-živců), slíd a glaukonitu v pískovcích spodních vrstev godulských korelují se zvýšenými koncentracemi K. Ve stejném období vysoké kon- 


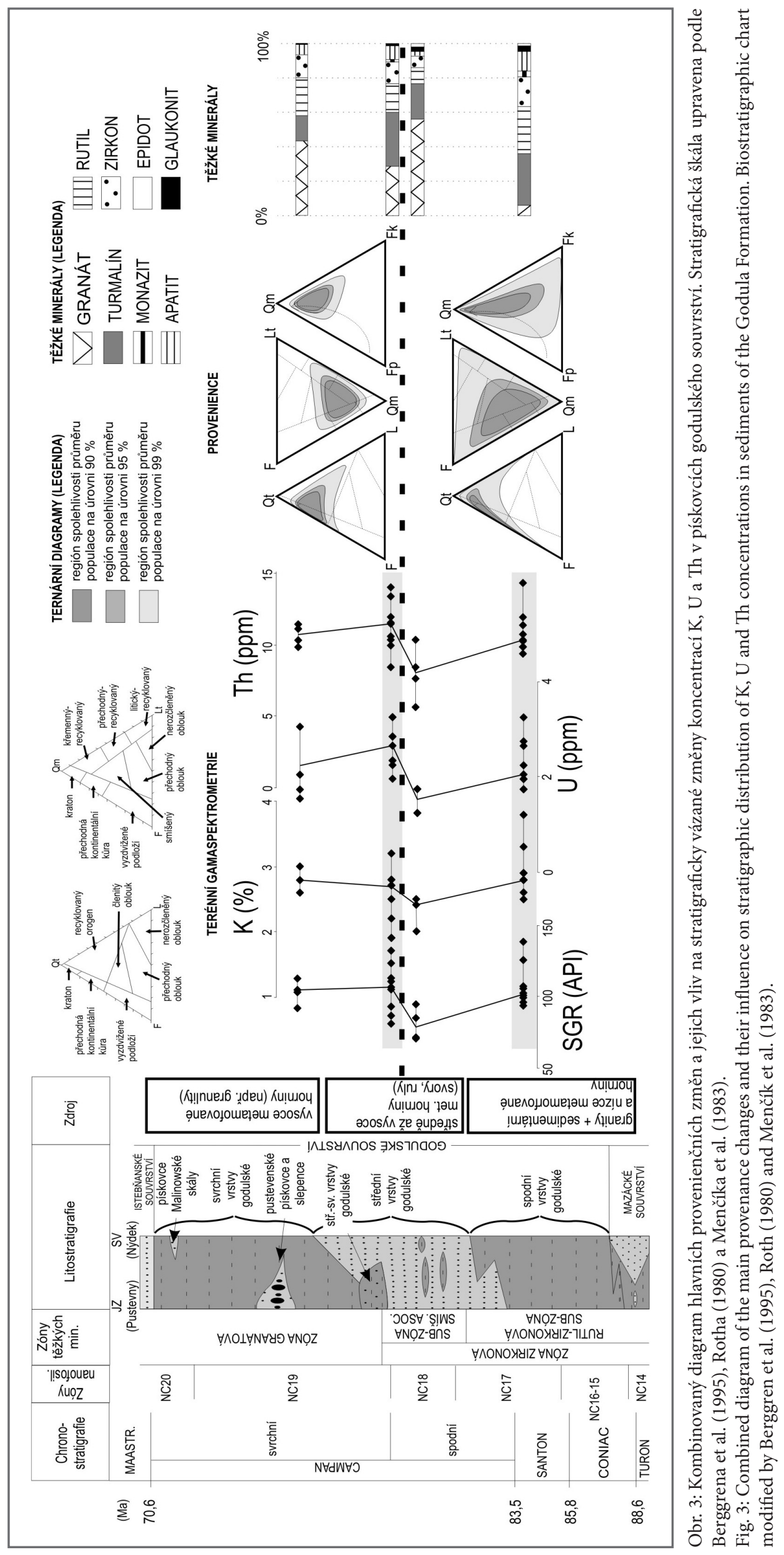


Tab. 4: Stratigrafické změny obsahů hlavních kompozičních skupin pískovců. SpVG - spodní vrstvy godulské, StřVG - střední vrstvy godulské, Stř̌-SvVG - střední až svrchní vrstvy godulské, SvVG - svrchní vrstvy godulské.

Tab. 4: Stratigraphic variations of contents of main sandstone compositional groups. SpVG - Lower Godula beds, StřVG - Middle Godula beds, Stř-SvVG - indiscrimated Middle to Upper Godula beds, SvVG - Upper Godula beds.

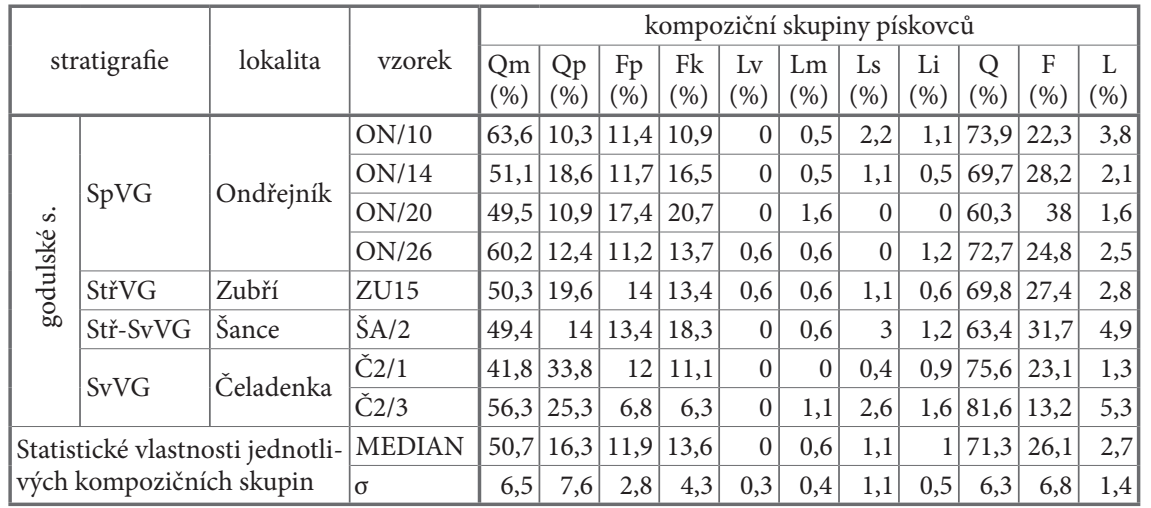

těles v terénu. Zvláště významná se jeví možnost odlišení pískovců na hranici středních a svrchních vrstev godulských od výrazně méně radioaktivních pískovců spodní části středních vrstev godulských, jejichž litostratigrafické rozlišení v terénu je často problematické (cf. Menčík et al. 1983, Eliáš 2000).

Poměr Th/U, který slouží jako indikátor redoxního potenciálu (Adams -Weaver 1958), se pohyboval od 2 do 7 , což jsou hodnoty typické pro sedimentaci v marinním prostředí. Obecný pokles průměrných hodnot poměru $T h / U$ do stratigraficky mladších členů godulského sou-

centrace U a Th korespondují s relativně vysokými podíly zirkonu a monazitu v asociacích těžkých minerálů. Snížení podílů zirkonu a monazitu v důsledku snižujícího se vlivu granitoidních hornin na celkové modální složení pískovců, je doprovázeno na bázi středních vrstev godulských zřetelným poklesem koncentrací U a Th. V tomtéž období došlo ke snížení obsahů draselných živců, což pravděpodobně způsobilo pokles koncentrací K (viz obr. 3). Na hranici středních a svrchních vrstev godulských byl v pískovcích pozorován zřetelný pokles minerální zralosti (viz tab. 4), což lze připsat zvýšené tektonické aktivitě v zázemí pánve v důsledku austrijských kompresních pohybů v alpsko-karpatské oblasti (Poprawa et al. 2002, Oszczypko 2004, Skupien - Mohamed 2008). Ve stejném období dosahuje celková radioaktivita pískovců svých maximálních hodnot. Především se výrazně zvyšují koncentrace $U$ a Th. Tento nárůst koresponduje se zvýšením obsahů zirkonu a apatitu v asociacích těžkých minerálů a kryje se zhruba se stropem subzóny smíšených asociací těžkých minerálů Rotha (1980). Ve svrchních vrstvách godulských pozorujeme jen mírné snížení celkové radioaktivity pískovců a pokles koncentrací U a Th v pískovcích, které lze nejspíše připsat efektu naředění neradioaktivním křemenem, $v$ důsledku zvýšené provenience materiálu z vysoce metamorfovaných hornin charakteru granulitů. Změny modálního složení pískovců a výsledky gamaspektrometrie podporují představu o postupné hloubkové erozi variských až povariských obalových jednotek slezské kordiléry a exhumaci jejího kadomského krystalinního jádra (Unrug 1968, Menčík et al. 1983, Michalík et al. 2004). Gamaspektrometrie může rovněž přispět ke stratigrafickému rozlišení pískovcových vrství se shoduje s předpokládaným nárůstem anoxických podmínek v průběhu jeho sedimentace (Menčík et al. 1983).

\section{Závěr}

Draslík je ve studovaných pískovcích vázán na horninotvorné i akcesorické detritické minerály (draselné živce, albit, muskovit, biotit, glaukonit). Hlavní zdroje U a Th byly identifikovány $\mathrm{v}$ akcesorických těžkých minerálech, jako jsou monazit a zirkon. Využití gamaspektrometrie $\mathrm{k}$ interpretacím zrnitosti pískovců a jako indikátoru facií se ukázalo být v daném prŕpadě problematické. Obecně nízká minerální zralost sedimentů a malý kompoziční kontrast mezi zrny písčité frakce a základní hmotou pískovců nedovolují detailnější gamaspektrometrické rozlišení facií. Změny v koncentracích K, U a Th jsou tak spíše spojeny se změnami v modálním složení pískovců godulského souvrství a indikují postupnou erozi sedimentárních a nízce metamorfovaných obalových jednotek a plutonického a vysoce metamorfovaného krystalinního jádra zdrojové oblasti. Terénní gamaspektrometrické studium pískovců godulského souvrství odhalilo možnosti využití přirozené radioaktivity sedimentů ke stratigrafickému rozlišení pískovcových těles. Na základě celkového GRS charakteru lze poměrně dobře odlišit pískovce svrchních a spodní části středních vrstev godulských. Terénní gamaspektrometrie tak může být vhodnou doplňkovou stratigrafickou metodou vzhledem ke špatnému makroskopickému a litostratigrafickému odlišení sedimentů obou členů godulského souvrství. 


\section{Literatura}

Adams, J. A. - Weaver, C. E. (1958): Thorium-uranium ratios as indicators of sedimentary processes: example of koncept of geochemical facies. - Bulletin of the American Association of Petroleum Geologists, 42, 2, 387-430.

Basu, A. (1985): Reading provenance from detrital quartz. - In: Zuffa, G. G. (ed.): Provenance of Arenites. NATO ASI, Series C, 148, 231-248. D. Reidel Publishing Company, Dordrecht.

Berggren, W. A. - Kent, D. V. - Swisher, C. C. III - Aubry, M. - P., Hardenbol, J. (1995): Geochronology, Time Scales. - SEPM Special Publications, 54, 386 pp. Tulsa.

Das, P. K. (2008): Petrography of sandstones of Thekopili Formation, Jaintia Hills district, Meghalaya. - Bulletin of Pure and Applied Sciences - Section F Geological Sciences, 27, 19-24.

Deer, W. A. - Howie, R. A. - Zussman, J. (1992): An introduction to the rock-forming minerals. $2^{\text {nd }}$ ed. - Longman Scientific \& Technical. 698 pp. Harlow.

Dickinson, W. R. (1970): Interpreting detrital modes of graywacke and Arcose. - Journal of Sedimentary Petrology, 40, 695-707.

Dickinson, W. R. - Beard, S. - Brakenridge, G. R. - Drnavec, J. L. - Ferguson, R. C. - Inman, K. F. - Knepp, R. A. - Lindberg, F. A. - Ryberg, P. T. (1983): Provenance of North American Phanerozoic sandstones in relation to tectonic setting. GSA Bulletin, 94, 2, 222-235.

Doveton, J. H. (1994): Geologic Log Interpretation: Reading the Rocks from Wireline Logs. - SEPM Short Course Notes, 29. 169 pps. Tulsa.

Eliáš, M. (1970): Litologie a sedimentologie slezské jednotky v Moravskoslezských Beskydech. - Sborník geologických věd, Geologie, 8, 7-99.

Eliáš, M. (2000): Vztahy mezi pústevenskými pískovci a pískovci malinovské skály (godulské souvrství s. s.) v Beskydách. - Geologické výzkumy na Moravě a ve Slezsku v roce 1999, 64-66.

Grzebyk, J. - Lesczyñski, S. (2006): New data on heavy minerals from the Upper Cretaceous-Paleogene flysch of the Beskid Slaski Mts. (Polish Carpathians). - Geological Quarterly, 50, 2, 265-280.

Helmond, K. P. (1985): Provenance of Feldspatic Sandstones - The Effect of diagenesis on Provenance interpretation. - In: Zuffa, G., G. (ed.): Provenance of Arenites. NATO ASI, Series C, 148, 139-163. D. Reidel Publishing Company, Dordrecht.

Matýsek, D. - Skupien, P. (2005): Fosforitové konkrece ve svrchní kř́ídě slezské jednotky. - Geologické výzkumy na Moravě a ve Slezsku v roce 2004, 34-36.

Menčík, E. - Adamová, M. - Dvořák, J. - Dudek, A. - Jetel, J. - Jurková, A. - Hanzlíková, E. - Houša, V. - Peslová, H. - Rybářová, L. - Šmíd, B. - Šebesta, J. - Tyráček, J. - Vašiček, Z. (1983): Geologie Moravskoslezských Beskyd a Podbeskydské pahorkatiny. - Ústřední Ústav geologický. 307 str. Praha.

Michalík, M. - Gehrels, G. - Budzyń, B. (2004): Dating of gneissic clasts from Gródek on the Jezioro Rożnowskie Lake (Silesian unit). - Materiały VII Ogólnopolskiej Sesji Naukowej “Datowanie Minerałów i Skał”, Kraków, AGH-UJ, 18-19. 11. 2004, $101-106$.

Morton, A. C. (2003): Heavy Minerals. - In: Middleton, M. J. et al. (eds): Encyclopedia of Sediments and Sedimentary Rocks. 356-358. Kluwer Academic Publishers. Dordrecht.

Oszczypko, N. (2004): The structural position and tectonosedimentary evolution of the Polish Outer Carpathians. - Przegląd Geologiczny, 52, 780-791.

Picha, F. J. - Stráník, Z. - Krejčí, O. (2006): Geology and Hydrocarbon Resources of the Outer Western Carpathians and Their Foreland, Czech Republic. - In: Golonka, J. - Picha, F. J.: The Carpathians and their foreland: Geology and hydrocarbon resources: AAPG Memoir, 84, 49-175.

Poprawa, P. - Malata, T. - Oszczypko, N. (2002): Ewolucja tektoniczna basenów sedymentacyjnych polskiej czêoeci Karpat zewnêtrznych w oewietle analizy subsydencji. - Przegląd Geologiczny, 50, 1092-1108.

Rider, M. (1996): The Geological Interpretation of Well Logs, $2^{\text {nd }}$ edition. - Whittles Publishing. 280 pps. Caithness.

Roth, Z. (1980): Stratigrafie godulské skupiny Moravskoslezských Beskyd ve světle hlubokých vrtů. - Věstník Ústř̌edního Ústavu geologického, 55, 2, 75-83.

Skupien, P. - Mohamed, O. (2008): Campanian to Maastrichtian palynofacies and dinoflagellate cysts of the Silesian Unit, Outer Western Carpathians, Czech Republic. - Bulletin of Geosciences, 83, 2, 207-224. Praha.

Slatt, R. M. - Jordan, D. W. - D'Agostino, A. - Gillespie, R. H. (1992): Outcrop gamma-ray logging to improve understanding of subsurface well log correlations. - In: Hurst, A. - Griffiths, C. M. - Worthington, P. F. (eds): Geological application of wireline logs ( $\left.2^{\text {nd }} E d\right)$. Special Publication - Geological Society of London, 65, 3-19.

Speer, J. A. (1980): Zircon. - Reviews in Mineralogy and Geochemistry - Mineralogical Society of America, 5, 67-112.

Svendsen, J. B. - Hartley, N. R. (2001): Comparison between outcropspectral gamma ray logging and whole rock geochemistry: implications for quantitative reservoir characterisation in continental sequences. - Marine and Petroleum Geology, 18, 65-670.

Šimíček, D. - Bábek, O. - Leichmann, J. (2012): Outcrop gamma-ray logging of siliciclastic turbidites: Separating the detrital provenance signal from facies in the foreland-basin turbidites of the Moravo-Silesian basin, Czech Republic. - Sedimentary Geology, 261-262, 50-64.

Tucker, M. E. (2003): Sedimentary Rocks in the Field, $3^{\text {rd }}$ Edition: The Geological Field Guide Series. - John Wiley\&Sons Limited. 234 pp. New York.

Unrug, R. (1968): Kordyliera Śląska jako obszar Żródłowy materiału klastycznego piaskowców fliszowych Beskidu Śląskiego i Beskidu Wysokiego (Polskie Karpaty zachodnie). - Rocznik Polskiego Towarzystwa Geologicznego, 38, 81-164.

Van Wagoner, J. C. - Mitchum, R. M. - Campion, K. M. - Rahmanian, V. D. (1990): Siliciclastic sequence and stratigraphy in well logs, cores, and outcrops: concepts for high-resolution correlation of time and facies. - American Association of Petroleum Geologists - Methods in Exploration, 7, 99 pp. Tulsa. 